\title{
MJN THE POSITIVE EFFECT OF EDUCATIVE GAME TOOLS (PUZZLE) ON COGNITIVE LEVELS OF PRE-SCHOOL CHILDREN (4-5 YEARS)
}

\author{
Rita Dwi Pratiwi ${ }^{1 *}$, Riris Andriati ${ }^{1}$, Fenita Purnama Sari Indah² \\ ${ }^{1}$ Widya Dharma Husada Tangerang School of Health Science, Indonesia \\ ${ }^{2}$ Kharisma Persada School of Health Science, Indonesia \\ *Corresponding Author's Email: ritadwipratiwi@wdh.ac.id
}

\begin{abstract}
Children at the Pre-school age i.e. at 3-5 years old shows progressively motoric, cognitive, social and social skill development. In daily life, children must be given a stimulus to help the improvement and development of cognitive function at the early age. Playing at the early-age for children is very necessary. By playing, the learning process will be effective and promptly perceived when they play. One of the media of playing for children that function to stimulate cognitive development is puzzle game. Puzzle is a piece of thin paper comprising 2-3 pieces even 4-6 pieces that are made of wood or cardboard. One of the benefits of playing is good for development of children's cognitive side. The aim of this research is to find out the influence of educative tool of game (puzzle) on the cognitive development of 4-5years old pre-children at RW.011 Pondok Pinang, Jakarta City Indonesia. The design of this research used pre-experiment with one-group pretest-posttest design approach. The sample consisted of 44 respondents by using non-probability sampling method. The result of Wilcoxon test on the intervening group obtained $p$ value 0.0000 meaning there was influence on intervening group. Based on the above result, that giving educative tool of game like puzzle is suggested in order to improve the development of children's cognitive side.
\end{abstract}

Keywords: Educative Game Tool, Puzzle, Cognitive Development, Pre-School Children

\section{INTRODUCTION}

Puzzle is a game that requires patience and perseverance in assembling children. Puzzles are thin pieces of paper consisting of 2-3 pieces or even 4-6 pieces made of wood or cardboard slabs. By getting used to playing puzzles, gradually the child's mental and cognitive development will also get used to being calm, diligent and patient in getting things done (Aral, Gursoy $\&$ Yasar, 2012). The satisfaction obtained when a child completes a puzzle is also one of the motivation for children to find new things. The benefits of puzzles as playing media are to improve cognitive skills, cognitive skills related to the ability to learn and solve problems. Through children's puzzles, they will try to solve the problem, namely by arranging the image to be whole (Suyadi, 2009).

About $16 \%$ toddlers in Indonesia reported experiencing developmental disorders in the form of intelligence disorders due to disorders of brain development, hearing loss and motoric disorders according to the Ministry of Health of Republic of
Indonesia. In 2010 disruption of growth and development in children in Indonesia reached 35.7\% and is classified as a public health problem which is quite high according to WHO's reference because it is still above 30\% (Sandjaja et al., 2013).

Based on WHO data in the world in 2009 the number of educated children stimulated by their parents amounted to $23.5 \%$ while in 2010 it reached $27.30 \%$ and in 2011 there was a significant increase to reach $34.85 \%$, whereas in Indonesia in 2012 the number of children given educational games in 2010 reached 24,120 people and in 2011 reached 25,100. With the number of preschoolers in Indonesia amounting to 9,451,943 people. But the problem remains because there are still many children who have not been stimulated by educational games. Pre-school period covers the ages between 3 and 6 years old (Dougherty et al., 2015). Supporting physical and cerebral development contributes much to the development of pre-school children. Child starts to socialize in these ages. His environment and the received stimulus play a crucial role in physical, mental, social and cognitive development 
and growth of the child (Howie, 2016; Wilks, CollierBaker \& Nielsen, 2015; Christensen et al., 2014; Kaya \& Efe, 2016).

Based on research conducted by Sugari (2014), puzzle games have effectiveness in improving cognitive development in children with ADHD (Attention Deficity Hyperactife Disorder). Previous research in this region showed that children could not recognize colors, had difficulty in classifying objects using one characteristic, such as collecting round objects or different colors. Based on this the researchers were interested in conducting the present study. So, this research will try to identify the effect of educational games (puzzles) on the cognitive level of preschool children (4-5 years) in RW 011 Pondok Pinang Jakarta City Indonesia

\section{METHODOLOGY}

Based on the background and theoretical review, a description and conceptual framework are obtained which in this study the researcher wants to find out more about the influence of educational (puzzle) game tools on the cognitive level of preschoolers (4-5 years) in RW 011 Pondok Pinang. The alternative hypothesis $(\mathrm{Ha})$ in this study is the influence of educational tools (puzzles) on the cognitive level of preschoolers in RW 011 Pondok Pinang. The design of this study uses the PreExperiment method with one group pretest-post test design approach (Sugiono, 2016) where the researcher describes how the influence of playing puzzle on cognitive level in preschool children (4-5 years) in RW 011 Pondok Pinang. The time of this research study was carried out from May 10, 2018. Population is the whole or a set of research objects that are examined (Notoatmojo, 2012). The population in the study were preschoolers in RW 011 Pondok Pinang totaling 50 children. The samples taken in this research are using the Issac and Michael Formulas.

There is 44 persons for sample. The inclusion criteria in this study are willing to be a respondent, preschoolers (4-5 years), children willing to play puzzle games, parents allowing children to be respondents. The exclusion criteria are children having limitations in communication, children with congenital defects. The research used Wilcoxon test.

\section{RESULTS}

The results of the study are in the form of univariate and bivariate analysis. Univariate analysis was carried out on the respondent characteristics data (age, gender, parental education, living environment, description of children's cognitive values before being given intervention in puzzle games and description of children's cognitive values after puzzle intervention). Educational puzzle game on the cognitive level of preschoolers (4-5 years) in RW 011 pinang cottage.

\section{Univariate Analysis}

The frequency distribution of respondents based on age, gender, parents' last education and living environment can be seen in the following table.

a. Age

In the table 1 above, it can be seen that the majority of respondents were 5 year-old children as many as 33 respondents $(75 \%)$ compared to the number of children aged 4 years were as many as $11(25 \%)$.

Table 1: Age distribution of preschool children in $R W$ 011 Pondok Pinang

\begin{tabular}{|l|l|l|}
\hline Age & (n) & (\%) \\
\hline 4 years & 11 & 25 \\
\hline 5 years & 33 & 75 \\
\hline Total & 44 & 100 \\
\hline
\end{tabular}

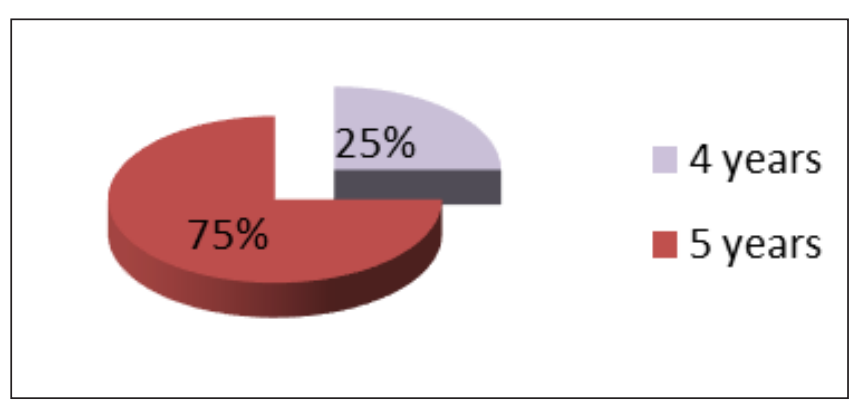

Figure 1. Pie Chart: Age distribution of preschool children in RW011Pondok Pinang

\section{b. Gender}

Based on the table 2 above, the male children consisted of 12 respondents $(27.3 \%)$ and the female children are 32 respondents $(72.7 \%)$.

Table 2: Distribution of Respondents by Gender

\begin{tabular}{|c|c|c|}
\hline Sex & (n) & (\%) \\
\hline Male & 12 & 27.3 \\
\hline Female & 32 & 72.7 \\
\hline Total & 44 & 100 \\
\hline
\end{tabular}




\section{c. The last education of parents}

From the table above, it can be seen that the characteristics of the parents of respondents based on the last education consisted of 5 groups. There's no parent of primary-school graduate. The parents with high-school background are 28 persons. About 11 parents are collegegraduates. While 4 parents come with master's degree.

Table 3: Distribution of the Last Education of Respondent Parents

\begin{tabular}{|l|c|c|}
\hline Parent's Education & N & $(\mathbf{\%})$ \\
\hline Primary School & 0 & 0.0 \\
\hline Middle School & 1 & 2.3 \\
\hline High School & 28 & 63.6 \\
\hline College & 11 & 25.0 \\
\hline Master's Degree & 4 & 9.1 \\
\hline Total & 44 & 100 \\
\hline
\end{tabular}

Middle
School
- College

\section{d. Living Environment}

Based on table 4, it can be seen that there are more preschoolers living in village areas as much as 26 $(59.1 \%)$

\section{Table 4: Living Environment Distribution}

\begin{tabular}{|l|c|c|}
\hline Neighborhood & (n) & $(\mathbf{\% )}$ \\
\hline Village & 26 & 59.1 \\
\hline Residence & 18 & 40.9 \\
\hline Total & 44 & 100 \\
\hline
\end{tabular}

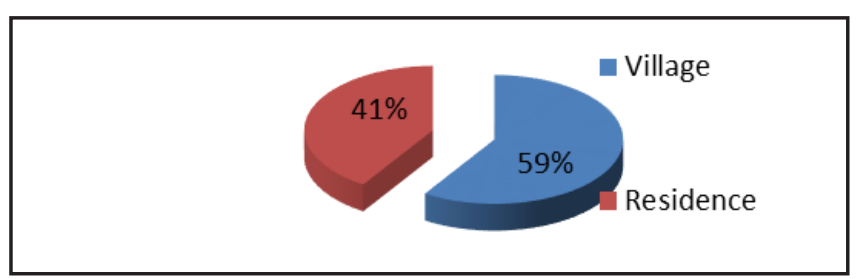

Figure 3: Pie Chart: Living Environment Distribution

e. Pretest the cognitive level of the child

Based on Table 5, it can be seen that cognitive development of preschoolers is not good with the number of respondents being as many as 30 children $(68.2 \%)$ compared to the number of children with good cognitive score that is equal to 14 children $(31.8 \%)$.

Table 5: Distribution of Child Cognitive Development Scores Before Intervention

\begin{tabular}{|l|l|l|}
\hline Pretest & (n) & (\%) \\
\hline Poor & 30 & 68.2 \\
\hline Good & 14 & 31.8 \\
\hline Total & 44 & 100 \\
\hline
\end{tabular}

\section{f. Postest the cognitive level of the child}

Based on table 6, it can be seen that cognitive development of preschoolers has increased considerably after being given an intervention with a number of cognitive development in the good category was seen among 35 children (79.5\%) and poor cognitive development was seen among children as many as 9 children $(20.5 \%)$.

Table 6: Distribution of Scores of Child Cognitive Development after Intervention

\begin{tabular}{|l|c|c|}
\hline Postest & (n) & (\%) \\
\hline Poor & 9 & 20.5 \\
\hline Good & 35 & 79.5 \\
\hline Total & 44 & 100 \\
\hline
\end{tabular}

\section{Bivariate Analysis}

Bivariate analysis is an analysis that will explain whether there is an influence between educative puzzle on cognitive development of preschool age children (45 years) in RW 011 Pondok Pinang based on the number of respondents ( 44 children).

Based on table 7 cognitive development of 2 children decreased after being given intervention, but cognitive improvement of 23 children was noted after being given an intervention, and 19 children had no changes in cognitive development.

Table 7: Effect Analysis of Educational Puzzle Game Tools on Cognitive Development of Preschool Children (4-5 years) in RW 011 Pondok Pinang

\begin{tabular}{|c|c|c|c|}
\hline & N & Mean Rank & Sum of Ranks \\
\hline PosttestPretest Negative Ranks & $2^{\mathrm{a}}$ & 13.00 & 26.00 \\
\hline Positive Ranks & $23^{\mathrm{b}}$ & 13.00 & 299.00 \\
\hline Ti es & $19^{\mathrm{c}}$ & & \\
\hline Total & 44 & & \\
\hline
\end{tabular}


a. Posttest $<$ Prettes $=$ cognitive development post experiment $<$ pre experiment cognitive development'

b. Posttest $>$ Prettes $=$ cognitive development post experiment $>$ pre experiment cognitive development

c. Posttest $=$ Prettes $=$ cognitive development post experiment $=$ pre experiment cognitive development

Table 8 showed the results of the Wilcoxon test were poor. The results of calculations ( $p$-value 0.000 ) because the $p$ value $<0.05$ is statistically significant difference in cognitive development of children before intervention and after intervention with educational puzzle games.

Table 8: Wilcoxon Test Analysis Results of Educational Puzzle Games before (pre) and as simple (post) $(N=44)$

\begin{tabular}{|c|c|c|c|}
\hline Mean Rank & Sum of 1 & & Pvalue \\
\hline Pre treatment 13.00 & 26.00 & \multirow{2}{*}{0.000} & \\
\hline Post treatment 13.00 & 299.00 & & \\
\hline
\end{tabular}

\section{DISCUSSION}

\section{Discussion of Univariate Analysis Results}

\section{a. Age}

Characteristics of preschoolers based on age divided were namely children aged 4 years as much as $25 \%$ and children aged 5 years as much as $75 \%$. According to Piaget, at this age children enter the preoperational period in which the thinking of children are egocentric, children can classify objects using one traits, such as collecting all the round objects or different colors. Preschool children are children aged 3-6 years who have not taken elementary school (Weisz, 2018).

Based on the research of three child education experts from America, namely Dr. Keith Osborn (University of Georgia), Dr. Button L. White (Preschool Project) and Prof. Dr. Benjamin S. Bloom (Universitiy of Chicago), the development of child's intellectual brain level begins at the age of 4 years old as much as $50 \%$, for this period is often called the golden age because the child during this time, absorb quickly every stimulus that enters (Hidayat, 2010). Pre-school period covers the ages between 3 and 6 years old (Dougherty et al., 2015). Along with this physical and cerebral development contributes much to the development of pre-school children. Child starts to socialize in these ages. His environment and the received stimulus play a crucial role in physical, mental, social and cognitive development and growth of the child (Howie, 2016; Wilks, 2015; Christensen, 2014).

\section{b. Parents' Last Education}

From the analysis, the results of the characteristics of the respondents based on the last education were divided into 5 groups. There's no parent of primaryschool graduate. There is $1(23 \%)$ parent of Middle School graduate. The parents with high-school background are 28 persons (64\%). About 11 (25\%) parents are college-graduates. While $4(9 \%)$ parents come with master's degree.

Parental education is the level or stage of education that students take, in their efforts to develop physically and spiritually, or through the process of changing intellectual and emotional ways of thinking or behavior. Parents will be a role model for children, children usually will imitate everything the parents do. So parents must be able to provide good examples and habits so that they can be used as good models for their children. Setting good examples and practicing good habits, should be given by parents since the time of their childhood because it can affect the development of the child's soul (Yusinta, 2016).

\section{c. Living Environment}

It can be seen that more children live in Village. There are 26(59.1\%) children and those who live in residential areas are 18 (40.9\%) children. Human beings are born as a sacred being like a clean sheet of paper with no tint at all are known as the Tabula Rasa theory or the Blank State. The level of intelligence is determined by the experience and knowledge gained from the environment of a good relationship in the child's environment, certainly affecting the cognitive development of children. The first education center is a family environment. Therefore, education in a family environment is very strategic to increase intelligence, built character or personality and preparation for life in society (Yusinta, 2016).

\section{d. Cognitive Development of Children}

From the results of the Wilcoxon test based on table 6 and 7 , the calculation results ( $p$-value 0.000 ) because it is found that the $p$ value $<0.05$ is statistically significant difference between before the treatment and after giving an educational puzzle game. The cognitive level of pre and post children in the intervention group got the average cognitive development of children before intervention with the poor category as many as 30 
children with a percentage of $68.2 \%$ and a good cognitive enhancement category of 14 children with a percentage of $31.8 \%$ and the results of cognitive enhancement of post-intervention children were in the category of unfavorable cognitive development as many as 9 children with a percentage of $20.5 \%$ and good cognitive development categories of children as many as 35 children with a percentage of $79.5 \%$ in addition to getting $P=0.000<0.05$. It found that there was a average increase in cognitive development of children before and after the intervention was given, thus (Ha) in this study was accepted and (Ho) was rejected.

There were 2 children with decreased cognitive development after being given intervention, 23 children had cognitive improvement after being given intervention, and 19 children had no changes in cognitive development. Child development will take place continuously especially in childhood. The child begins to experience a fairly rapid development because children aged 4-6 years show the ability to perform activities to move more, develop curiosity, and explore objects around them (Susanto, 2011).

\section{Discussion of Bivariate Analysis Results}

\section{Effect of children's educational games}

From the results of the Wilcoxon test, there is a different result of the calculation ( $p$-value 0.000) because the $p$ value $<0.05$ is statistically significant between before the treatment and after giving an educational puzzle game. The results obtained were that there were influences of educational puzzle games on the cognitive level of preschoolers (4-5 years) at RW011 Pondok Pinang. There was decrease in children cognitive development among 2 respondents after intervention, 23 children had cognitive improvement after being given intervention and 19 children had no changes in cognitive development.

This research is in line with Sugari's Research (2014) that there is a difference after giving an educational puzzle game. Based on the table above, it can be seen that cognitive development of preschoolers before intervention is still not good with the number of respondents being 30 children $(68.2 \%)$ compared to the number of children with good cognitive score that is equal to 14 children $(31.8 \%)$. The cognitive development of preschoolers has increased considerably after being given an intervention with a number of cognitive developments is on the good category among 35 children $(79.5 \%)$ and cognitive development of poor children as many as 9 children (20.5\%). Besides this research is in line with research conducted by Sugari (2014) which concluded that there was an influence of puzzle games on ADHD children's cognitive level. The result of other research which support this research is Suryastini's research (2014), her research's result concluded that there is a significant influence between puzzle games and children's language development. Also puzzle games influences children's visual-spatial intelligence (Anjani, 2014) and puzzle games influences cognitive development in children aged 5-6 years (Muloko, 2016).

The most important educational materials at preschool educational institutions and home environment are games and gaming materials. Children identify and evaluate what is happening in their surrounding and outside world through the medium of play materials. Play materials are the most valuable means for stimulating intelligence, senses and emotions; and developing the imagination and creativity of the child, as well as supporting physical, spiritual and social development. Defined as a subcategory of play materials, educational materials improve child's learning through playing and accordingly helping them to form some concepts and understand objects and events in a better way (Kandir \& Tezel, 2011). Puzzles are effectual educational materials which support children's cognitive, language, motor, social and emotional developmental areas while fostering their creativity and self-care skills as well as providing learning during playing with them. Therefore, use of puzzles by practitioners and parents to support children's development and their academic skills is important (Aral, Gursoy \& Yasar, 2012). Cognitive development is the development of thinking or intelligence, namely the ability to learn new skills and concepts, skills to understand what is happening in the environment as well as the skills to use memory and solve simple questions (Novan, 2014). Giving puzzle games to children is an interesting method and provides knowledge that can hone the child's strategic skills. The given game can give a symbol concluded that there was an influence of puzzle games on children's cognitive level.

\section{CONCLUSIONS}

In this chapter we present conclusions and suggestions from the results of research. There are influences on respondents before and after being given treatment, namely cognitive enhancement of children based on the results of the Wilcoxon test of the calculation ( $p$-value 0.000 ) because the value of $p<0.05$ is statistically significant. Thus (Ha) is accepted and 
(Ho) rejected, which means that there is an influence of educational (puzzle) game tools on the cognitive level of preschoolers (4-5 years) in RW 011 Pondok Pinang.

The results of this study provide an overview to educational institutions regarding the importance of the game as a learning media to stimulate children's cognitive development, especially for teaching staff as an input in the learning process so that children can be given educational games to improve their cognitive development. The results of this study can be used as a health promotion to parents. From this study it was evident that play is the natural process by which young children learn. Even if the preschoolers are just playing, their brains are hard at work putting together vital knowledge about the world. Games are an important form of entertainment for children and through this child organize independently and they have special educational significance. We should understand that these are powerful tool for education because through games children acquire knowledge, enrich their experience, and develop skills and habits.

\section{ACKNOWLEDGMENT}

This research was supported by Mr. M. Hasan. The researchers would also like to thank all of those who helped in this research, especially for our Proofreaders, The Typists, and the others who helped at RW 011 Pondok Pinang Jakarta City Indonesia.

\section{REFERENCES}

Anjani, D.A. \& Nurjanah, S.(2014). Permainan Puzzle Mempengaruhi Perkembangan kecerdasan visual-spatial anak usia 4-5 tahun di TK Al-fath desa Kebon Anom Gedangan Sidoarjo. Journal Ilmiah Kesehatan, 7(2), pp 186-192.

Aral, N., Gursoy, F. \& Yasar, M.C. (2012). An Investigation of the Effect of Puzzle Design on Children's Development Areas. Procedia - Social and Behavioral Sciences, 51, pp 228-233.

Christensen, D., Schieve, L., Devine, O. \& Drews-Botsch, C. (2014). Socioeconomic status, child enrichment factors and cognitive performance among preschool-age children: results from the follow-up of growth and development experiences study. Research in Developmental Disabilities, 35(7), pp 1789-801.

Dougherty, L.R., Leppert, K.A., Merwin, S.M., Smith, V.C., Bufferd, S.J. \& Kushner, M.R. (2015). Advances and Directions in Preschool Mental Health Research. Child Development Perspective, 9(1), pp 14-19.

Hidayat, A.A. (2010). Pengantar Ilmu Kesehatan Anak. Jakarta: Salemba Medika

Howie, E.K., Brewer, A.E., Dowda, M., McIver, K.L., Saunders, R.P. \& Pate, R.R. (2016). A Tale of Two Teachers: A Preschool Physical Activity Intervention Case Study. Journal of School Health, 86(1), pp 23-30.

Kandir,A.\& Tezel Sahin, F. (2011). Okul öncesi dönemde oyuncak ve oyun materyalleri: Egitici oyuncaklar [Toys and play materials in early childhood period: Educational toys]. Istanbul: Morpa Kültür Publishing. [In Turkish]

Kaya, A. \& Efe, E. (2016). Review Article: Pre-School Period of Development. Annals of Nursing and Practice, 3(2), 1044.

Muloko, I.C., Ismanto, A.Y. \& Bataha, Y. (2016). Pengaruh Alat Permainan Edukatif Puzzle Terhadap Perkembangan KognitifAnak Usia 5-6 Tahun Desa Linawan Mangondow Selatan. e-Journal Keperawatan(e-Kp), 5(1).

Notoatmodjo, S. (2012). Clinical Research Methodology. Jakarta: EGC

Novan, A.W. (2014). Psikologi Perkembangan Anak Usia Dini. Yogyakarta: Gava Media.

Sandjaja, S., Budiman, B., Harahap, H., Ernawati, F., Soekatri, M., Widodo, Y., Sumedi, E., Rustan, E., Sofia, G., Syarief, S.N. \& Khouw, I. (2013). Food consumption and nutritional and biochemical status of 0.5-12-year-old Indonesian children: the SEANUTS study. British Journal of Nutrition. 110(Suppl 3), pp S11-20.

Sugari, P.N. (2014). Efektifitas Permainan Puzzle Terhdap Perkembangan Kognitif Anak ADHD (Attention Deficit Hyperactive Disorder) Di SLB Nasional Desa Sudimara Kecamatan Cilongok Kabupaten Banyumas. Bachelor thesis, Universitas Muhammadiyah Purwokerto, Indonesia 
Suryastini, L.A., Wirya, N. \& Ujianti, P.R. (2014). Penerapan Metode Pemberian Tugas Perbantuan Media Puzzle Huruf Untuk Meningkatkan Perkembangan Bahasa Pada Anak TK. Jurusan Pendidikan Anak Usia Dini, 2(1).

Susanto, A. (2011). Perkembangan Anak Usia Dini. Jakarta: Kencana Prenada. Media Group.

Suyadi. (2009). Permainan Edukatif Yang Mencerdaskan. Yogyakarta: Power Books (Ihdina).

Weisz, E.R. (2018). Piaget Theory: Childhood cognitive developmental stages. Cognifit Health brain Neuroscience. Retrieved from: https://blog.cognifit.com/piaget-theory/

Wilks, M., Collier-Baker, E. \& Nielsen, M. (2015). Preschool children favor copying a successful individual over an unsuccessful group. Developmental Science, 18(6):1014-1024.

Yusinta, D.A. (2016). Pentingnya Peran Orang Tua Terhadap Pendidikan Anak. Yogyakarta: STIKes AlmaAta. 